\title{
Otel Atmosferinin Turistik Tüketicilerin Tekrar Satın Alma Niyetine Etkisi
}

\section{The Effect of Hotel Atmosphere on Tourist Customers' Repurchase Intention}

\section{Selen LEVENT}

Kocaeli Üniversitesi

Soyal Bilimler Enstitüsü

E-posta: selennn013@gmail.com
Prof. Dr. Emrah ÖZKUL

Kocaeli Üniversitesi

Turizm Fakültesi, Kocaeli, Türkiye E-posta: emrah.ozkul@kocaeli.edu.tr

\section{Öz}

$\mathrm{Bu}$ araştırmada otel atmosferinin turistik tüketicilerin tekrar satın alma niyetlerine etkisinin ölçülmesi amaçlanmıştır. Bu doğrultuda otel atmosferinin beş boyutu incelenmiştir. Araştırmanın verileri, kolayda örneklem yöntemi ile İstanbul'daki 5 yıldızlı otellerde konaklayan turistlerden anket tekniğinde yararlanılarak toplanılmıştır. Elde edilen verilerin regresyon analizine tabi tutulması sonucunda otel atmosferinin tekrar satın alma niyeti üzerinde bir etkisinin olduğu tespit edilmiştir. Otel atmosferi boyutları açısından değerlendirildiğinde ise; dış ve insani değişkenlerin turistlerin tekrar satın alma niyetleri üzerinde anlamlı bir etkisi olduğu ancak genel iç, iç yerleşim ve kayıt yeri değişkenlerinin bir etkisinin olmadığı sonucuna ulaşılmıştır.

Anahtar Kelimeler: Otel atmosferi, Tekrar satın alma niyeti, Turistik tüketici

\section{Abstract}

In this study, it is aimed to measure the effect of hotel atmosphere on repeat purchasing intention of touristic consumers. In this direction, five dimensions of the hotel atmosphere have been examined. The data of the research were collected from the tourists staying in 5 star hotels in Istanbul with the convenience sampling method, using the survey technique. As a result of the regression analysis of the obtained data, it has been determined that the hotel atmosphere has an effect on the repurchase intention. When the hotel atmosphere is evaluated in terms of its dimensions; It is concluded that external and human variables have a significant effect on tourists' repurchase intention, but general internal, internal settlement and registration location variables do not.

Key Words: Hotel atmosphere, Repurchase intention, Tourist consumer

\footnotetext{
* Bu araştırma Doç. Dr. Emrah Özkul danışmanlığında Yüksek Lisans Öğrencisi Selen Levent tarafından tamamlanan "Otel Atmosferinin Tekrar Satın Alma Niyetine Etkisi" başlıklı yüksek lisans tezinden türetilmiştir.
} 


\section{Extended Abstract}

\section{Purpose}

In this study, it is aimed to measure the effect of hotel atmosphere and its dimensions on repeat purchasing intention of touristic consumers.

\section{Background}

When the litterateur regarding the area of the study is examined, the atmosphere of the hotel; it has been determined that it is examined with the variables of customer loyalty, experience, perception and service quality. However, there is no study on repeat purchasing intention, which is a sub-segment of customer loyalty. Therefore, measuring the effect of hotel atmosphere on repurchase intention reveals the original value of the research.

\section{Method}

In this study, the survey technique has been used as a data collection tool. The data of the study, the data of the study has been collected by the convenience sampling method, domestic tourists aged 18 and over who stayed at least once in one of the 5star hotel businesses in Istanbul. The data obtained has been limited to regression analysis in order to measure the effect of hotel atmosphere and dimensions of hotel atmosphere on repurchase intention.

\section{Findings}

In the study, it has been determined that the hotel atmosphere has an effect on repeat purchasing intention. When the hotel atmosphere is evaluated in terms of its dimensions, it has been revealed that external and human variables have a significant effect on tourists' repeat purchase intention; however the variables of general interior, internal settlement and record location do not have an effect.

\section{Results}

As a result of the study, it has been determined that the hotel atmosphere has a positive and significant effect on the repeat purchasing intention of tourist consumers. This determination can be explained by the fact that service businesses are able to provide consumers with more experience compared to other businesses. Finally, this study offers various suggestions to business managers and future researchers about the hotel atmosphere, which has an impact on the repurchase intention of touristic consumers.

\section{Giriş}

Turistik tüketiciler konaklama deneyimlerini farklı unsurlar üzerinden değerlendirmektedir. Sistem özelliği ve alt sistemlerin birbirine bağlı olduğu bir yaklaşımla turizm işletmelerinde hangi unsurların ön plana çıktığı sıklıkla araştırma konusu olmaktadır. Otel işletmelerinin; duygusal, duyusal, düşünsel, ilişkisel ve davranışsal olarak beş boyuttan oluşan deneyimsel pazarlama bileşenleri, bireylerin beklenti ve gereksinimlerinin tahmin edilmesinde kullanılmaktadır. İşletmelerde çekicilik oluşturma ve eğlence sunma çabaları turistik tüketicilerin deneyimleri açısından yetersiz kalabilmektedir. Bu nedenle işletmeler deneyim oluştururken "otel atmosferi" gibi farklı boyutlardan da yararlanılmaktadır. Otel işletmelerinin iç ve dış görünümü, 
düzenlenmesi, kayıt ve yerleşim yerlerinin dizaynı, ürünlerin sunumu, kullanılan renkler, ışıklandırma, havalandırma, koku, müzik, çalışanların görünümü, kullanılan iletişim kanalları olarak ele alınan bu boyutlar, turistik tüketicilerin hizmet kalitesi algılamalarını ve satın alma davranışlarını etkileyebilmektedir.

$\mathrm{Bu}$ araştırmada, öncelikle atmosfer kavramı ile turizm endüstrisindeki yapısı ve kapsamı incelenmiştir. Otel atmosferi ve turistik tüketicilerin tekrardan satın alma niyeti arasındaki ilişki açıklanmaya çalışılmıştır. Yöntem bölümünde; araştırmanın amacı, hipotezi, evren ve örneklemi ile veri toplama yöntemine ilişkin bilgilere yer verilmiş, bulgular, literatürde yer alan ilgili çalışmalar ile tartışılmıştır. Son olarak çalışmanın sonuçları ve kısıtlarına yer verilip çeşitli önerilerde bulunulmuştur.

\section{Otel Atmosferi}

Atmosfer kavramının birden çok anlamı vardır. Hem iş hayatında hem de günlük hayatta anlam bulan bir kavramdır. Atmosfer; "belli bir yerde belli bir zamanda bireylerin toplam deneyimini etkileyen duyular üzerinde etkisi olan uyarıcılar (atmosferik değişkenler) demektir" (Akkuş Karkın, 2009: 166). Kotler (1974: 48-50) tarafından ise atmosfer "satın alıcılarda etki yaratmak amacıyla alanların bilinçli bir şekilde dizayn edilmesi" şeklinde tanımlamıştır. Pazarlama alanında atmosferin sınıflandırılması konusunda farklı görüşleri bulunmaktadır. Kotler atmosferi beş duyu ile tanımlarken, Turley ve Milliman (2000), Berman ve Evans ile ele aldıkları değişkenlere beşinci değişken olan insan değişkenini de eklemiştir. Barker ve Parasuraman'a göre çoklu çevre değişkenlerinin tekrar satın alma niyeti üzerindeki etkilerini inceledikleri çalışmada belirli faktörler ile tanımlamışlardır. Spries, Hesse ve Loesch çevresel psikoloji modelinden faydalanarak atmosfer özelliklerinin tüketicilerin duygu ve ruh halleri ile satın alma davranışı arasında bir bağ olduğunu savunmaktadır. Son olarak Bitner'in atmosfer sınıflandırması ise alışveriş atmosferi üzerine olup, alışveriş çevresinin boyutlarına göre bir atmosfer sınıflandırması yapmıştır (Yeniçeri Alemdar, 2010: 154-178).

Hizmetler sektörünü diğer sektörlerden ayıran bazı temel özellikler bulunmaktadır. $\mathrm{Bu}$ nedenle hizmetlerin tüketici deneyimleri açısından daha iyi değerlendirilebilmesi adına somut kanıtlara intiyaç duyulmaktadır. Tüketicilere somut kanıtlar sunabilmek için işletmelerin yararlandığı kavramlardan biri de atmosfer unsurlarıdır. Özellikle hastaneler, bankalar ve oteller gibi hizmet sektörü işletmelerinin, tüketicilerin memnuniyetleri üzerinde etkili olan fiziksel atmosfer unsuruna dikkat etmeleri gerekmektedir (Booms ve Bitner, 1982: 35).

Kotler (1963) atmosferin görme, koku, ses ve dokunma duyularına hitap edilerek oluşturulmasını; Bitner (1992) ise mekânsal düzen, ortam koşulları (koku, ses, estetik) ve işlevsellik (işaretler, semboller) olarak üç boyutta düzenlenmesini belirtmiştir. Diğer yandan Turley ve Milliman (2000) atmosfer boyutlarını; genel dış, genel iç, yerleşimtasarım, satış noktası-dekorasyon ve insani değişkenler olarak sınıflandırmıştır.

Literatürde atmosfer kavramını ele alan farklı turizm işletmeleri ile ilgili yapılan çalışma sayısı fazla iken otel atmosferini ele alan çalışmaya az sayıda rastlanmaktadır. Sapsford (1995) bar ortamında oluşturulan atmosfer boyutlarının kadınları, erkeklere oranla daha fazla etkilediğini ve bu nedenle kadınların daha sadık tüketici olduklarını ifade etmiştir. Lin ve Matilla (2010) restoran atmosferinin; Schmidt ve Lam vd. (2011) ise kumarhane atmosferinin tüketici memnuniyeti üzerinde etkili olduğunu sonucuna varmıştır. Ariffin vd. (2012) otel atmosferinin, tüketicilerin tavsiye ve tekrardan ziyaret etme niyeti; Temeloğlu vd. (2017) müşteri memnuniyeti; Altun ve Ayyıldız (2020) 
müşteri tatmini; Aksu (2012) ise müşteri sadakati üzerinde etkili olduğunu belirtirken; Ayazlar ve Artuğer (2015) otellerde; mekânsal tasarım, araç gereçler, mobilyalar, işaretler, sanat eserleri ve dekor gibi atmosferik unsurların tüketiciler için farklı anlamları olduğunu vurgulamıştır.

Otel işletmelerinde atmosfer; genel dış, genel iç, yerleşim-tasarım, satış noktasıdekorasyon ve insani değişkenler olarak sınıflandırımıştır. Yapılan bu sınıflandırma aşağıdaki gibi özetlenmektedir (Demirci, 2000; Arslan, 2004; Yolcu, 2006; Varlender ve Yakhlef, 2006; Kurt, 2008; Aksu, 2012);

Genel Otel Dışı Değişkenler: Turistik tüketicilerin ilk izlenim ve algısı otelin dış görünümüne göre şekillenmektedir. Bu nedenle işletmelerin dikkat çekici düzeyde bir görünüme sahip olması gerekmektedir. Son yıllarda önem kazanan dış değişkenler, otel yöneticilerinin odak noktası haline gelmektedir. Bu değişkenler; otelin mimari yapısı, rengi, çevre düzeni ve ulaşım imkanları gibi unsurları kapsamaktadır.

Genel Otel İçi Değişkenler: Bir otel işletmesinin içerisinde var olan atmosferin ferahlığı, turistik tüketicilerin 0 işletmede geçirmek isteyecekleri süre ile doğru orantılıdır. Bu husus doğrultusunda işletmeler tüketicilere; temiz, iyi bir aydınlatmaya sahip, duvar renkleri uyumlu ve düzenli bir ortam sunarak etkili bir deneyim yaşatmaktadır.

Genel Otel Içi Yerleșim Değişkenleri: Ürün, demirbaş, kasa ve koridor gibi alanların yerleşimi bu değişkenlerin unsurları olarak ifade edilmektedir. Fakat yerleşim değişkenleri kapsamında konum ve görüntü dışında estetik ve atmosfer uyumu da yer almaktadır. Otel işletmelerinde yerleşim planı yapılırken tüketicilerin satın almaya teşvik edilmesi ve çalışanların motivasyon/verimliliği amacıyla etkinlik ön planda tutulmaktadır.

Otel Kayıt Yeri Değişkenleri: Bu değişkenler otel içerisinde resepsiyon, danışma bankoları ve lobi alanlarını kapsamaktadır. Konukların; resepsiyon, toplantı salonları, restoranlar ve rekreasyon alanları gibi bölümlere ulaşmasından kayıt yeri sorumludur. Atmosfer unsurlarına uygun olarak düzenlenen kayıt yeri, otelin imajı hakkında bilgilendirici bir niteliğe taşımaktadır.

Otel Çalışanları Değişkenleri: Otel işletmelerinin turistik tüketiciler tarafından olumlu ya da olumsuz algılanmasında; çalışanlarının davranışları, konuşmaları, giyimleri ve tüketici profilleri etkilidir. Bu nedenle işletmelerin, atmosfer oluştururken çalışanlara yönelik değişkenlere dikkat etmeleri gerekmektedir.

\section{Turistik Tüketicinin Tekrar Satın Alma Niyeti}

Turistik tüketici; "kendisinin ve ailesinin turistik ihtiyaç/isteklerini karşılamak amacıyla bir tatil satın alma niyetinde olan, turistik ürün/hizmetleri satın alan gerçek bireyler" olarak tanımlanmıştır (Şahan, 2016: 27). Turistik tüketici davranışı ise; "bireylerin seyahatleri boyunca duydukları gereksinim/ihtiyaçlarını karşılayan ürünleri, hizmetleri ve düşünceleri araştırmak, satın almak ve değerlendirebilmek amacıyla bulundukları her türlü davranışlar" olarak ifade edilmiştir. Genel tüketim davranışı için ortaya çıkarılan uygulamalı ve kuramsal bilgiler genellikle turistik tüketici davranışlarını da içermektedir (Asanbakova, 2007).

Turistik tüketicilere ait bu davranışların tahmin edilmesinde satın alma niyeti kavramının katkısı büyüktür. "Tüketicilerin ürün/hizmeti satın alma isteğini ve bu 
ürün/hizmeti gelecek bir zamanda alabileceği ihtimalinin ortaya koyulması" olarak tanımlanan satın alma niyeti (Heljıc, 2015: 35) mevcut pazarın eğilimlerinin anlaşılmasına ve konumlandırılmasına olanak sağlamaktadır (Mei Fang ve Chia Lin, 2015). Tekrar satın alma niyeti kavramı ise tüketicinin belirli bir zaman sonucunda daha önce satın aldığı ürün/hizmeti sahip olmaya yeniden niyetlendiği bir davranıştır. $\mathrm{Bu}$ davranış başta müşteri tatmini olmak üzere; kolaylık, istek, hizmet kalitesi, deneyimler, müşteri aşinalığı, işletmenin sadık müşterisi olunması faktörlerinden etkilenmektedir (Hume vd., 2007: 137).

Macintosh ve Lockshin (1997) hizmet kalitesinin, turistik tüketicilerin tekrar satın alma niyetleri ve işletmeye olan sadakatleri üzerinde etkili olduğundan söz etmişlerdir. Otel işletmelerinin türüne (butik, büyük ölçekli vb.) göre deneyimlerin turistik tüketicilerin memnuniyetleri üzerinde etkili olduğu pek çok çalışma sonucunda ortaya çıkmaktadır (Güney, 2015; Uşaklı, 2016; Çetin ve Walls, 2016 ve Ali vd. 2016). Yang (2008) ve Çabuk vd. (2013) otel işletmelerindeki hizmet kalitesinin tekrar satın alma niyeti üzerinde etkili olduğunu belirtmişlerdir. İfade edildiği gibi tekrar satın alma niyeti başta müşteri tatmini ile ilişkilidir. Bu ilişkiden ve incelenen çalışmalardan yola çıkılarak otel işletmelerinde oluşturulan atmosferin, tekrar satın alma niyeti üzerinde olumlu ya da olumsuz bir etkisinin olacağı düşünülmektedir.

\section{Araştırmanın Yöntemi}

\subsection{Araştırmanın Amacı, Hipotezleri ve Modeli}

Araştırma probleminin tespit edilmesinden hareketle yapılan literatür incelemesi sonucunda, bu çalışma kapsamında otel atmosferinin turistik tüketicinin tekrar satın alma niyeti üzerine olan etkisinin araştırılması amaçlanmaktadır. Çalışma kapsamında ele alınan temel amaç doğrultusunda ana hipotez ve alt hipotezler oluşturulmuştur.

Countryman ve Jang (2006) yaptıkları araştırmada renk, aydınlatma ve stil gibi atmosferik unsurların müşteri izlenimiyle önemli ölçüde ilişkili olduğu sonucuna ulaşmıştır. Akkuş Karkın (2009) ise otel işletmelerinde hizmet atmosfer ortamının oluşturulmasını kuramsal bir çerçevede incelemiştir. Atmosfer kavramının sadece fiziksel niteliklere sahip olmadığını bunun dışında işitsel vb. gibi faktörlerin de etkili olunabileceği belirtilmiştir. Hussain ve Ali (2015) temizlik, koku, aydınlatma gibi atmosferik değişkenlerin tüketici satın alma niyetini olumlu yönde etkilediğini, fakat müzik ve rengin bu niyet üzerinde olumlu bir etkiye sahip olmadığını ifade etmişlerdir. Literatürde yer alan çalışmalarda otel atmosferinin; müşteri sadakati, müşteri algısı ve demografik özellikler ile ilişkisi de incelenmektedir. (Aksu, 2012; Heide ve Gronhaug, 2009; Ayazlar ve Artuğer, 2015). Ayrıca otel atmosferinin müşteri sadakati üzerinde anlamlı bir etkiye sahip olması, müşteri sadakati parametrelerinden biri olan tekrar satın alma niyeti ile ilişkilendirilmesine neden olmaktadır. Ransles ve Ingram (2001) mimari açıdan oldukça başarılı bir otelin satışlarını artırdığını, Lin (2004) atmosfer unsurunun hizmet üzerinde büyük bir öneme sahip olduğunu, özellikle restoranlarda müşteriler üzerinde ilk izlenimi oluşturmada büyük bir role sahip olduğunu ifade etmiştir. Heide ve Grounhaug (2006) atmosfer kavramı ile müşteri memnuniyetinin; Harris ve Ezeh (2008) sadakat niyetinin arasında bir ilişki olduğunu savunmuşlardır. Aksu (2012) otel atmosferi boyutlarından sadece otel içi yerleşim ve otel çalışanları değişkenlerinin müşteri sadakati üzerinde etkili olduğunu vurgulamakta; otel atmosferinin kapsadığı beş boyutla müşteri algısı, satın alma ile etkileri incelenmiş ve bunların atmosfer kavramı üzerinde etkili oldukları görülmüştür. Fakat müşteri sadakati üzerinde her bir değişkenin anlamlı bir etkiye sahip olduğunu söylemek güçtür. 
Literatür incelemesinden elde edilen bulgular neticesinde $\mathrm{H} 1$ hipotezi aşağıdaki şekilde oluşturulmuştur.

H1: Otel atmosferinin turistik tüketicilerin tekrar satın alma niyetine etkisi vardır.

Bu çalışmada otel atmosferi değişkenleriyle birlikte tanımlandığı için aşağıdaki alt boyutlarla test edilmiştir.

$H_{1 a}:$ Otel atmosferinin değişkenlerinden genel dış değişkenlerinin turistik tüketicilerin tekrar satın alma niyetine etkisi vardır.

$\boldsymbol{H}_{1 b}$ : Otel atmosferinin değişkenlerinden genel iç değişkenlerinin turistik tüketicilerin tekrar satın alma niyetine etkisi vardır.

$\boldsymbol{H}_{1 c}$ : Otel atmosferinin değişkenlerinden yerleşim ve tasarım değişkenlerinin turistik tüketicilerin tekrar satın alma niyetine etkisi vardır.

$\boldsymbol{H}_{1 d}$ : Otel atmosferinin değişkenlerinden kayıt yeri değişkenlerinin turistik tüketicilerin tekrar satın alma niyetine etkisi vardır.

$H_{1 e}:$ Otel atmosferinin değişkenlerinden otel çalışanları ile ilgili değişkenlerinin turistik tüketicilerin tekrar satın alma niyetine etkisi vardır.

Şekil 1: Araştırma Modeli

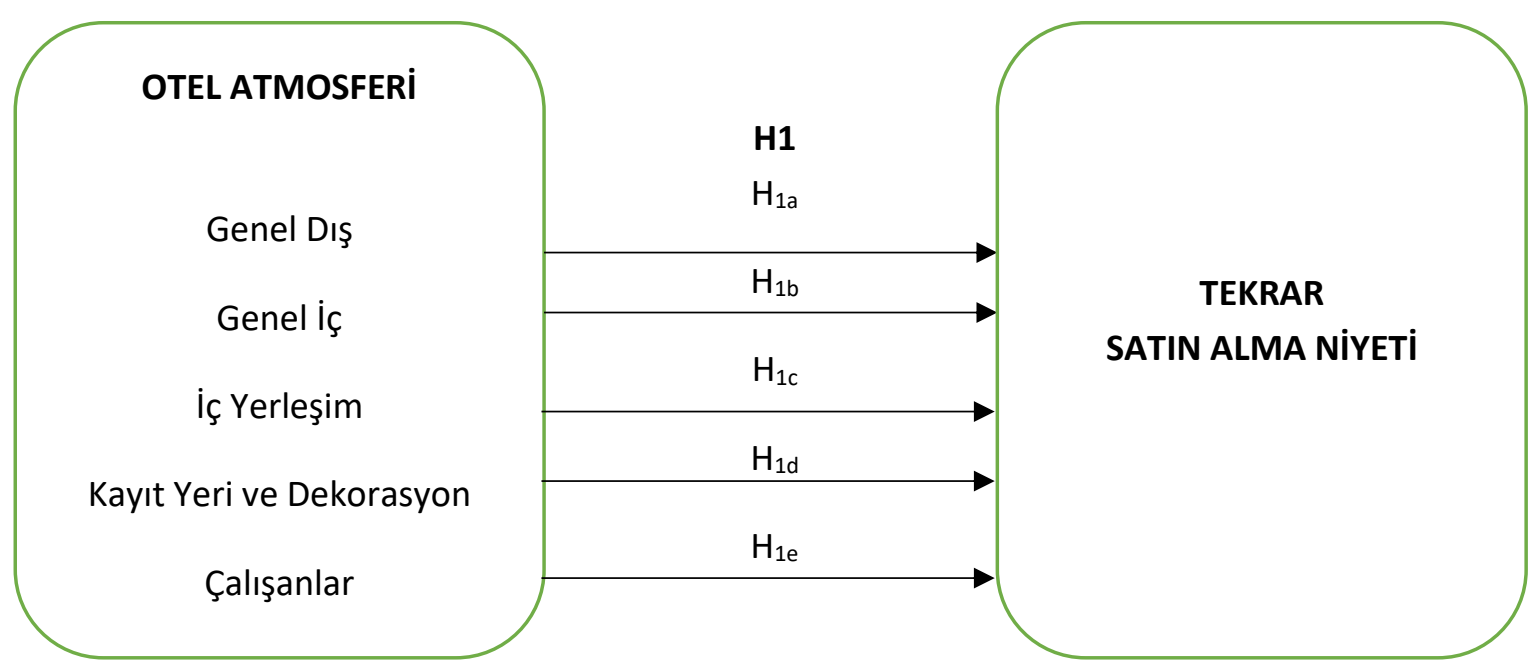

\subsection{Araştırmanın Evreni ve Örneklemi}

Hazırlanan araştırmanın evrenini, 24.08.2019 tarihli Kültür ve Turizm Bakanlığı'na bağlı İstanbul'da bulunan toplam 130 turizm yatırım belgeli ve turizm işletme belgeli 5 yıldızlı otel işletmelerinden birinde en az bir kez konaklamış olan, 18 yaş ve üzeri yerli turistler oluşturmaktadır. Birden fazla konaklama söz konusu ise anket formunu son konakladıkları otele göre değerlendirmeleri talep edilmiştir. Araştırma kapsamında evrenin tamamına ulaşılması mümkün olmadığından dolayı örnekleme yoluna gidilmiştir. Yeterli bir örneklem, güvenilir sonuçlar sağlayacak kadar eleman kapsayan örneklemdir (Young, 1968: 324). Bu nedenle araştırmada örneklem büyüklüğü \%95 güven aralığında ve \%5 örnekleme hata payı ile belirlenmiştir. 
Yapılan hesaplamalar bağlamında anket formunu doldurmayı kabul eden bireyler, tesadüfi olmayan örnekleme yöntemlerinden kolayda örnekleme yöntemine göre örnekleme alınmıştır. Kolayda örnekleme, isteyen herkesin örneklem içerisine dahil edilmesine dayanan bir yöntemdir. Denek bulma işlemi belirlenen örneklem hacmine ulaşıncaya kadar devam etmektedir. Bu örnekleme yöntemi gerek zaman gerekse ekonomik açıdan çok büyük tasarruf sağlamaktadır (Ural ve Kılıç 2005: 38).

Araştırmada veriler toplanmadan önce anketin anlaşılırlığının belirlenmesi ve geçerlilik güvenilirlik değerlerinin test edilebilmesi amacıyla 1-5 Ekim 2019 tarihleri arasında pilot çalışma gerçekleştirilmiştir. 30 kişi ile gerçekleştirilen pilot çalışma verilerinin analizi sonucunda anketlerin anlaşılır olduğu tespit edilirken, güvenilirlik ve geçerlilik değerlerinde de araştırmanın yapılabilir olduğu desteklenmektedir. Çalışmanın verileri, 7-31 Ekim 2019 tarihleri arasında anket tekniği ile toplanmıştır. Elde edilen verilerin 259'u yüz yüze, 151'i online platformlar aracılığıyla olmak üzere toplamda 410 anket formu değerlendirmeye alınmıştır. Bu araştırmaya 2020 yılından önce başlanması sebebiyle etik kurul raporu alınmamıştır, fakat akademik etik ilkeler dikkate alınarak veriler toplanmıştır.

\subsection{Veri Toplama Yöntemi ve Aracı}

Araştırmada veri toplama aracı olarak anket tekniği kullanılmıştır. Anket formu üç bölümden oluşmaktadır. İlk bölümde turistlerin kaldıkları 5 yıldızlı otellere göre algılama düzeylerini belirlemek amacıyla "Atmosfer Ölçeği" yer almaktadır. Turley ve Milliman (2000) tarafından hazırlanan çalışmada yer alan "Mağaza Atmosfer Ölçeğinden" yararlanılmıştır. Yalçın (2002), Kurt (2008) ve Ercan (2008) tarafından pazarlama alanında Türkçeleştirilen atmosfer ölçeği, Aksu (2012) tarafından otel atmosferine uyarlanmıştır. Ölçekte 5'li Likert Tipi derecelemesine göre 57 madde bulunmaktadır. 5'li dereceleme; 1 "kesinlikle katılmıyorum" dan 5 "kesinlikle katılıyorum" şeklinde ifade edilmektedir.

Tablo 1: Araştırma Ölçeklerinin Güvenilirlik Analizleri

\begin{tabular}{|c|c|c|c|c|}
\hline DEĞişKENLER & \multirow{2}{*}{$\begin{array}{l}\text { MADDE } \\
\text { SAYISI }\end{array}$} & \multirow{2}{*}{$\begin{array}{c}\text { GÜVENiRLíLiK } \\
(0,95)\end{array}$} & \multirow{2}{*}{$\begin{array}{l}\text { STANDART } \\
\text { SAPMA }\end{array}$} & \multirow[t]{2}{*}{ VARYANS } \\
\hline Otel Atmosferi Boyutları & & & & \\
\hline Genel Otel Dışı Değişkenler & 13 & 0.874 & ,69728 & ,486 \\
\hline Genel Otel İçi Değişkenler & 13 & 0.662 & ,67253 & ,452 \\
\hline Otel İçi Yerleşim Değişkenleri & 9 & 0.880 & ,71225 &, 507 \\
\hline Otel Kayıt Yeri Değişkenleri & 9 & 0.791 & ,79931 & 639 \\
\hline Otelde Çalışanlar İle İlgili Değişkenler & 13 & 0.842 & ,67661 & ,458 \\
\hline Tekrar Satın Alma Niyeti Değişkenleri & 5 & 0,702 & ,91865 & ,844 \\
\hline TOPLAM & 62 & & & \\
\hline
\end{tabular}

Tablo 1'de otel atmosferi boyutları, boyutlara ilişkin madde sayıları, güvenilirlik, standart sapma ve varyans oranları yer almaktadır. Cronbach's Alpha katsayılarına göre; "Genel Otel Dışı Değişkenler" (0,874); "Genel Otel İçi Değişkenler" $(0,662)$; "Otel İçi Yerleşim Değişkenleri” (0,880); "Otel Kayıt Yeri Değişkenleri” $(0,791)$ ve son olarak "Otel Çalışanları ile İlgili Değişkenler" $(0,842)$ olarak hesaplanarak ölçek güvenilir bulunmuştur. Araştırmanın ikinci bölümünde ise araştırmaya katılan turistlerin tekrar satın alma niyetini belirlemeye yönelik ölçeğe göre Cronbach's Alpha istatistiği 0,702 olarak hesaplanmıştır. 
Veri analizlerine geçilmeden önce verilerin normal dağılıp dağılmadığını tespit etmek amacıyla çarpıklık ve basıklık değerleri incelenmiştir. Tabachnick ve Fidell (2007) 100 ve üzerine çıkan örneklem sayılarında pozitiflikten kaynaklanan normal dağılım sorununun, örneklem sayısının 200 ve daha üstü bir sayıya ulaşmasında negatif basıklıktan kaynaklanan normal dağılım sorununu ortadan kaldırdığını ifade etmektedirler. Ayrıca verilerin normal dağılım koşulunun sağlanabilmesi için çarpıklık değerinin +3 ile -3 arasında olması gerektiği belirtilmektedir. Basıklık değerinin ise +10 ile -10 arasında bir değer alması gerektiği vurgulanmaktadır (Kline, 2016). Bu araştırmada ele alınan verilerin çarpıklık değerlerinin $+1,553$ ile $-0,215$ arasında, basıklık değerinin ise $+2,821$ ve $-1,212$ arasında değiştiği görülmüş ve normal dağılım gösterdiği kabul edilmiştir.

\section{Araştırmanın Bulguları}

Araştırmaya dahil edilen bulgular ortaya koyularak bu bulgulara ait değerlendirmeler yapılacaktır. İlk olarak katılımcıların demografik özelliklerini analiz etmek üzere frekans analizinin sonuçları sonrasında ise otel atmosferi ve otel atmosferinin boyutlarının tekrar satın alma niyeti üzerinde etkisini ölçmek adına yapılan regresyon analizi bulguları değerlendirilecektir.

\subsection{Katılımcıların Demografik Özellikleri}

Araştırmanın bu bölümünde araştırmaya dahil edilen katılımcıların demografik özelliklerine ait veriler frekans ve yüzde değerleri istatistiği kullanılarak değerlendirilmiştir. Değerlendirmeye ait bilgiler Tablo 2'de yer almaktadır.

\section{Tablo 2: Katılımcıların Demografik Özellikleri}

\begin{tabular}{|c|c|c|c|c|c|}
\hline Değişkenler & $\begin{array}{c}\text { Sıklık } \\
(\mathrm{N})\end{array}$ & $\begin{array}{c}\text { Yüzde Değeri } \\
(\%)\end{array}$ & Değişkenler & $\begin{array}{l}\text { Sıklık } \\
(\mathrm{N})\end{array}$ & $\begin{array}{c}\text { Yüzde Değeri } \\
(\%)\end{array}$ \\
\hline $\begin{array}{l}\text { Cinsiyet } \\
\text { Kadın } \\
\text { Erkek }\end{array}$ & $\begin{array}{l}194 \\
216\end{array}$ & $\begin{array}{l}47,3 \\
52,7\end{array}$ & $\begin{array}{l}\text { Otele Gelme Amacı } \\
\text { İş Amaçlı } \\
\text { Tatil Amaçlı }\end{array}$ & $\begin{array}{l}125 \\
285\end{array}$ & $\begin{array}{l}30,5 \\
69,5\end{array}$ \\
\hline $\begin{array}{l}\text { Yaş } \\
18-27 \\
28-37 \\
29-47 \\
48-57 \\
58 \text { ve üzeri }\end{array}$ & $\begin{array}{c}152 \\
116 \\
82 \\
32 \\
28\end{array}$ & $\begin{array}{c}37,1 \\
28,3 \\
20,0 \\
7,8 \\
6,8\end{array}$ & $\begin{array}{l}\text { Konaklama Süresi } \\
1-2 \text { gün } \\
\text { 3-4 gün } \\
5-6 \text { gün } \\
7 \text { gün ve daha fazlası }\end{array}$ & $\begin{array}{c}105 \\
122 \\
135 \\
48\end{array}$ & $\begin{array}{l}25,6 \\
29,8 \\
32,9 \\
11,7\end{array}$ \\
\hline $\begin{array}{l}\text { Öğrenim Düzeyi } \\
\text { İlköğretim/Ortaokul } \\
\text { Lise } \\
\text { Ön Lisans/Lisans } \\
\text { Lisansüstü }\end{array}$ & $\begin{array}{c}25 \\
94 \\
\mathbf{2 1 5} \\
76\end{array}$ & $\begin{array}{c}6,1 \\
22,9 \\
\mathbf{5 2 , 4} \\
18,5\end{array}$ & $\begin{array}{l}\text { Otel Hizmeti Alma Sıklığı } \\
\text { Haftada } 1 \\
\text { Ayda } 1 \\
3 \text { ayda } 1 \\
6 \text { ayda } 1 \\
\text { Yılda } 1 \text { kez } \\
\text { Yılda birden daha az }\end{array}$ & $\begin{array}{c}16 \\
25 \\
43 \\
79 \\
173 \\
74\end{array}$ & $\begin{array}{c}3,9 \\
6,1 \\
10,5 \\
19,3 \\
\mathbf{4 2 , 2} \\
18,0\end{array}$ \\
\hline $\begin{array}{l}\text { Otelden Alınan Hizmet ile } \\
\text { İlgili Problem }\end{array}$ & & & Otelde Tekrar Konaklama & & \\
\hline $\begin{array}{l}\text { Evet } \\
\text { Hayır }\end{array}$ & $\begin{array}{c}76 \\
334\end{array}$ & $\begin{array}{l}18,5 \\
81,5\end{array}$ & $\begin{array}{l}\text { Evet } \\
\text { Hayır }\end{array}$ & $\begin{array}{l}303 \\
107\end{array}$ & $\begin{array}{l}73,8 \\
26,2\end{array}$ \\
\hline
\end{tabular}

Tablo 2'ye göre katılımcıların dağılımları incelendiğinde \%52,7'sinin erkek, \%37,1'inin 18-27 yaş aralığında ve \%52,4'ünün ön lisans/lisans eğitimi aldığı görülmektedir. Araştırmada katılımcıların turistik davranışları incelendiğinde; \%69,5'inin tatil amaçlı, \%32,9'unun otellerde 5- 6 gün konakladıkları, \%42,2 'sinin yılda 1 kez otel 
hizmeti aldıkları, \%81,5'inin otelden alınan hizmet ile ilgili problem yaşamadıkları ve \%73,8'inin konakladıkları otelde tekrardan konaklamayı düşündükleri gözlemlenmektedir.

\subsection{Otel Atmosferi ve Boyutlarının Tekrar Satın Alma Niyeti Üzerindeki Etkisine Yönelik Gerçekleştirilen Regresyon Analizi ve Sonuçları}

Otel atmosferi (genel) değişkeninin tekrar satın alma niyeti üzerindeki etkisi basit doğrusal regresyon analizi ile test edilmiştir. Analize ait bulgular Tablo 3 ve Tablo 4'te yer almaktadır. Otel atmosferi boyutlarından dış değişkenler, iç değişkenler, yerleşim değişkenleri, kayıt değişkenleri ve insani değişkenlerinin tekrar satın alma niyeti üzerindeki etkisi ise çoklu regresyon analizi ile test edilmiştir. Analize ait bulgular Tablo 3 ve Tablo 4'te gösterilmektedir.

Tablo 3: Otel Atmosferi (Genel) - Tekrar Satın Alma Niyeti Modeli Özeti

\begin{tabular}{|c|c|c|c|c|c|c|}
\hline Model & $\mathbf{R}$ & $\mathbf{R 2}$ & $\begin{array}{c}\text { Düzeltilmiş } \\
\mathbf{R 2}\end{array}$ & ANOVA F & $\begin{array}{c}\text { ANOVA } \\
\text { Significant }\end{array}$ & Durbin- Watson \\
\hline Otel Atmosferi &, 384 &, 147 &, 145 & 70,487 &, 000 & 2,104 \\
\hline
\end{tabular}

Tablo 3 incelendiğinde, $\mathrm{R}$ değerinin \%38,4, determinasyon katsayısının \%14,7 ve düzeltilmiş katsayısının da \%14,5 olduğu görülmektedir. Analiz sonuçlarına göre $\mathrm{R}^{2}$ değeri incelendiğinde; tekrar satın alma niyetindeki değişmenin \%14,7'sinin, otel atmosferi (genel) değişkeni tarafından açıklandığı söylenebilir. Diğer bir ifadeyle "tekrar satın alma niyeti" davranışının \%14,7 oranında otel atmosferi (genel) değişkenine bağlı olarak şekillendiği anlaşılmaktadır. Hata terimleri arasında Durbin Watson katsayısı 2'ye yakın bir değer $(2,104)$ olduğundan otokorelasyonun olmadığı söylenebilir. Otel atmosferi ve tekrar satın alma niyetine ilişkin model $p<0,01$ önem düzeyinde anlamlıdır.

Modeldeki katsayıların tahmin değerleri ve bunlara ilişkin $t$ değerleri ise Tablo 4 'te yer almaktadır.

Tablo 4: Otel Atmosferi (Genel)- Tekrar Satın Alma Niyeti Modeli Katsayılar Tablosu

\begin{tabular}{|c|c|c|c|c|c|c|c|}
\hline \multirow{2}{*}{ Model } & \multicolumn{2}{|c|}{$\begin{array}{c}\text { Standardize Edilmemiş } \\
\text { Katsayılar }\end{array}$} & \multirow{2}{*}{\begin{tabular}{|c|}
$\begin{array}{c}\text { Standardize } \\
\text { Edilmiş Katsayılar }\end{array}$ \\
Beta
\end{tabular}} & \multirow{2}{*}{ T-değeri } & \multirow{2}{*}{ Anlamlılık } & \multirow{2}{*}{ TIF } & \multirow{2}{*}{ VIF } \\
\hline & B & $\begin{array}{l}\text { Standart } \\
\text { Hata }\end{array}$ & & & & & \\
\hline (Sabit) & 1,651 & 203 & & 8,150 & ,000 & & \\
\hline $\begin{array}{c}\text { Otel } \\
\text { Atmosferi }\end{array}$ & ,439 & ,052 & ,384 & 8,396 & ,000 & 1,000 & 1,000 \\
\hline
\end{tabular}

Otel atmosferi (genel) ve tekrar satın alma niyeti değişkenleri arasındaki ilişkiye ait regresyon denklemi (Tekrar Satın Alma Niyeti $=1,651+0,439^{*}$ Otel Atmosferi) olarak yazılır. Tablo 4'e göre; otel atmosferi (genel) değişkenindeki 1 birimlik artış, katılımcıların tekrar satın alma niyetlerini 0,439 birim arttıracaktır. Otel atmosferinin (genel) tekrar satın alma niyeti üzerindeki etkisinin kabul edilmesi bağlamında, H1 hipotezi (ana hipotez) desteklenmiştir. 
Tablo 5: Dış Değişkenler, İç Değişkenler, Yerleşim Değişkenleri, Kayıt Değişkenleri ve İnsanı Değişkenleri - Tekrar Satın Alma Niyeti Değişkeni Modeli Özeti

\begin{tabular}{|c|c|c|c|c|c|c|}
\hline Model & $\mathbf{R}$ & $\mathbf{R 2}$ & $\begin{array}{c}\text { Düzeltilmiş } \\
\mathbf{R 2}\end{array}$ & ANOVA F & ANOVA significant & $\begin{array}{c}\text { Durbin- } \\
\text { Watson }\end{array}$ \\
\hline $\begin{array}{c}\text { Otel Atmosferi } \\
\text { Boyutları }\end{array}$ &, $398^{\mathrm{a}}$ &, 158 &, 148 & 15,188 &, 000 & 2,138 \\
\hline
\end{tabular}

a. Bağımsız değişkenler: Dış Değişkenler, İç Değişkenler, Yerleşim Değişkenleri, Kayıt Değişkenleri ve İnsani Değişkenler

b. Bağımlı değişken: Tekrar Satın Alma Niyeti

Tablo 5'te otel atmosferi boyutlarından dış değişkenler, iç değişkenler, yerleşim değişkenleri, kayıt değişkenleri ve insani değişkenlerine göre R değerinin \%39,8 determinasyon katsayısının \%15,8 ve düzeltilmiş katsayısının da \%14,8 olduğu görülmektedir. Analiz sonuçlarına göre, otel atmosferi boyutlarından dış değişkenler, iç değişkenler, yerleşim değişkenleri, kayıt değişkenleri ve insani değişkenlerine ilişkin regresyon katsayısının açıklama oranı \%15,8'dir. Buna göre, "tekrar satın alma niyeti" davranışının \%15,8 oranında bu faktörlere bağlı olarak değişmektedir.

Modeldeki katsayıların tahmin değerleri ve bunlara ilişkin $t$ değerleri ise Tablo 6'da yer almaktadır.

Tablo 6: Dış Değişkenler, İç Değişkenler, Yerleşim Değişkenleri, Kayıt Değişkenleri ve İnsanı Değişkenleri-Tekrar Satın Alma Niyeti Değişkeni Modeli Katsayılar Tablosu

\begin{tabular}{|c|c|c|c|c|c|c|c|}
\hline \multirow[t]{2}{*}{ Model } & \multicolumn{2}{|c|}{$\begin{array}{l}\text { Standardize } \\
\text { Edilmemiş } \\
\text { Katsayılar }\end{array}$} & \multirow{2}{*}{\begin{tabular}{|c}
$\begin{array}{c}\text { Standardize } \\
\text { Edilmiş } \\
\text { Katsayılar }\end{array}$ \\
Beta
\end{tabular}} & \multirow[t]{2}{*}{ T- değeri } & \multirow[t]{2}{*}{ Anlamlılık } & \multirow[t]{2}{*}{ TIF } & \multirow[t]{2}{*}{ VIF } \\
\hline & B & $\begin{array}{c}\text { Standart } \\
\text { Hata }\end{array}$ & & & & & \\
\hline (Sabit) & 1,601 & ,205 & & 7,790 & ,000 & & \\
\hline $\begin{array}{l}\text { Dış Değişkenler- } \\
\text { Satın Alma Niyeti }\end{array}$ & ,192 & ,061 & ,199 & 3,174 &, $002^{*}$ &, 531 & 1,885 \\
\hline $\begin{array}{l}\text { İç Değişkenler- Tekrar Satın } \\
\text { Alma Niyeti }\end{array}$ &,- 014 & ,076 &,- 014 &,- 183 & ,855 & ,364 & 2,747 \\
\hline $\begin{array}{lc}\text { Yerleşim } & \text { Değiş̧kenleri- } \\
\text { Tekrar Satın Alma Niyeti }\end{array}$ & ,067 & ,067 & ,070 & ,986 & ,323 & ,410 & 2,438 \\
\hline $\begin{array}{l}\text { Kayıt Değişkenleri- Tekrar } \\
\text { Satın Alma Niyeti }\end{array}$ & ,018 & ,056 &, 021 & ,312 & ,755 & ,467 & 2,142 \\
\hline $\begin{array}{l}\text { İnsani Değişkenler- Tekrar } \\
\text { Satın Alma Niyeti }\end{array}$ & ,191 & ,068 & ,192 & 2,812 &, $005^{\star}$ & ,447 & 2,236 \\
\hline
\end{tabular}

${ }^{*} p>0.05$ anlamsız; $p<0.05$ anlamlı*; güvenilirlik: \% 95

Tablo 6'da yer alan katsayı (Coefficients), regresyon denklemi için kullanılan regresyon katsayılarını ve bunların anlamlılık düzeylerini vermektedir. Araştırmada dış değişkenler ve insani değişkenler ile tekrar satın alma niyeti arasındaki ilişki $p<0,05$ düzeyinde anlamlı iken, iç değişkenler, yerleşim değişkenleri ve kayıt değişkenleri ile tekrar satın alma niyeti arasındaki ilişkinin istatistiksel olarak anlamlı olmadığı görülmektedir. Bu bulgulardan hareketle otel atmosferi boyutlarından dış değişkenler ve insani değişkenlerin tekrar satın alma niyeti üzerinde anlamlı bir katkı sağladığı söylenebilmektedir. 
Otel atmosferi boyutlarından "dış değişkenler" ve "insani değişkenler" bağımsız değişkenlerinin "tekrar satın alma niyeti” bağımlı değişkeni üzerindeki etkisine yönelik regresyon denklemi;

Y $\left(\right.$ Tekrar Satın Alma Niyeti) $=1,601+0,192^{*}$ (Dış Değişkenler $)+0,191^{*}$ (İnsani Değişkenler) şeklinde yazılır.

Tabloda görüldüğü üzere dış değişkenler düzeyindeki 1 birim artış tekrar satın alma niyetini 0,192 (\%19,2) birim arttıracaktır. İnsanı değişkenler düzeyindeki 1 birim artış ise tekrar satın alma niyetini $0,191(\% 19,1)$ birim arttıracaktır $(p<0,01)$. Bu bağlamda, $\mathrm{H} 1 \mathrm{a}$ ve $\mathrm{H} 1 \mathrm{e}$ hipotezleri desteklenirken, $\mathrm{H} 1 \mathrm{~b}, \mathrm{H} 1 \mathrm{c}$ ve $\mathrm{H} 1 \mathrm{~d}$ hipotezleri desteklenmemiştir.

\section{Sonuç ve Öneriler}

$\mathrm{Bu}$ araştırma İstanbul özelindeki 5 yıldızlı otel işletmelerinin atmosfer ve boyutlarının tekrar satın alma niyeti üzerindeki etkisinin belirlenmesi amacıyla yapılmıştır. Araştırmanın yapıldığı alan ile ilgili literatür incelendiğinde otel atmosferinin; müşteri sadakati, müşteri deneyimi, müşteri algısı ve hizmet kalitesi gibi pek çok değişken ile incelendiği tespit edilmiştir. Fakat literatürde müşteri sadakatinin bir alt boyutu olan tekrar satın alma niyeti ile ilgili bir araştırmaya rastlanamamaktadır. Bu nedenle otel atmosferi ile müşteri sadakatinin bir alt boyutu olan tekrar satın alma niyetine etkisi ölçülmesi araştırmanın önemini vurgulamaktadır. Araştırmada dört mevsim turizm faaliyetlerinin devam ettiği bir il olan İstanbul seçilmiştir. İstanbul'daki 5 yıldızlı otellerde konaklayan yerli turistlere anket uygulanmıştır. Atmosfer kavramını oluşturabilme yeterliliğine sahip olan 5 yıldızlı otel işletmelerinin evreni temsil edebilmesi nedeniyle, İstanbul alan araştırması için tercih edilmiştir. Araştırmanın amacı doğrultusunda anket tekniği ile elde edilen veriler, basit doğrusal regresyon ve çoklu regresyon analizi ile test edilmiştir. Elde edilen bulgular, araştırmacılara var olan bilgilere dair genel bir bakış sunmaktadır. Aynı zamanda bulgular, araştırmacılar için uygulama ve literatür hakkında önemli ipuçları sunmaktadır. Bu araştırma, otel işletmeleri yöneticileri için, otel atmosferinin tüketici davranışları ve memnuniyeti üzerindeki etkisini anlayarak, otel işletmelerinin yeniden tercih edilebilir olabilmesi için hangi boyutların etkili olduğunun farkında olarak gerekli düzenlemelerin yapılmasına fırsat verecektir.

Atmosfer kavramı ile ilgili hizmet işletmelerinde gerçekleştirilen araştırmaların sonuçlarından ilki, işletmelerde yaratılan atmosferin tüketicilerin satın alma davranışlarını olumlu ve anlamlı bir şekilde etkilediğidir. Bu araştırma da ise hizmet işletmelerinden biri olan otellerde yaratılan atmosfer ortamının turistik tüketicilerin tekrardan satın alma niyetleri üzerinde olumlu ve anlamlı bir etkisinin olduğu tespit edilmektedir. Bu durum pazarlama alanındaki araştırmalarla (Bitner, 1992; Oakes, 2000; Heide vd., 2006; McNeil, 2009; Akkuş, 2009; Lin, 2010) paralel sonuçlar göstermektedir. Bu sonucun sebebi; hizmet işletmelerinin, diğer işletmelere kıyasla tüketicilere daha fazla deneyim yaşatabilmesinin mümkün olmasından kaynaklanıyor olabileceği tahmin edilmektedir. Araştırmanın bir diğer sonucu da otel atmosferi kavramının değişkenlerinden olan; genel iç değişkenler, yerleşim-tasarım değişkenleri ve kayıt yeri değişkenlerinin tekrar satın alma niyeti üzerinde olumlu ya da olumsuz bir etkisinin bulunmadığı yönündedir. Fakat bu sonuç alan yazında yer alan (Ratneshwar, 2000; Michon vd., 2005; Akaydın, 2007; Barlı, 2011; Bilgili, 2018) araştırmalarla uyuşmamaktadır. 
Otel atmosferinde çalışanlar ile ilgili değişkenlerin müşteri sadakatinin bir alt boyutu olan tekrar satın alma niyeti üzerinde etkili olduğu sonucuna ulaşılmıştır. Otel çalışanları değişkenin müşteri sadakati ve tekrar satın alma niyeti üzerindeki olumlu ve anlamlı etkisinin alan yazında yer alan (Akaydın, 2007; Hoffman vd., 2015; Emir 2016) araştırmalar ile benzer sonuçlar göstermekte iken, Aksu (2012) otel çalışanları ile ilgili değişkenlerin müşteri sadakati üzerinde anlamlı bir etkisinin olmadığını ifade etmiştir. Otel çalışanlarından olumlu izlenim alan tüketicinin bir işletmeyi tekrar ziyaret edebileceği, akrabalarına ve yakınlarına tavsiye edebileceği kaçınılmaz bir davranıştır.

Araştırmanın sonuçlarında otel içi yerleşim ve kayıt yeri değişkenlerinin tekrar satın alma niyeti üzerinde olumlu ya da olumsuz bir etkisinin olmadığı tespit edilirken, Aksu (2012) tarafından gerçekleştirilen araştırmada ise otel atmosferi boyutlarından otel içi yerleşim değişkenlerinin ve otel çalışanları ile değişkenlerin müşteri sadakati üzerinde bir etkisinin olmadığı ifade edilmiştir. Otel içi yerleşim değişkenleri açısından değerlendirildiğinde iki çalışma da paralel niteliktedir.

Araştırmanın sonucunda otel atmosferinin tekrar satın alma niyeti üzerinde olumlu bir etkisinin olduğu görülmüştür. Bu durum restoran atmosferinin tekrar satın alma niyeti üzerinde etkili olduğunun tespit edildiği Temeloğlu vd. (2017) tarafından gerçekleştirilen araştırma ile paralellik gösterdiği dikkat çekmektedir. Tüketicilerin tekrar satın alma niyetlerinde etkiye neden olan otel atmosferi, işletmeler tarafından dikkate alınmalıdır.

Otel atmosferinin tekrar satın alma niyetine etkisini ölçmeyi amaçlayan bu araştırma sadece otel işletmeleri ile sınırlı olduğu için geliştirilen öneriler; işletme yöneticileri ve bundan sonra konuyla ilgili yapılacak araştırmalara yönelik geliştirilmiştir. Bu öneriler;

- İstanbul'daki 5 yıldızlı otellerde gerçekleştirilen araştırma farklı illerde ya da farklı işletme türlerinde tekrarlanıp benzerlikler ya da farklılıklar ortaya çıkartılabilir.

- $\quad$ Elde Edilen sonuçlar neticesinde atmosfer boyutlarından genel otel içi, otel içi yerleşim ve kayıt yeri değişkenlerinin, İstanbul'da faaliyet gösteren 5 yıldızlı otel işletmelerinde konaklayan turistlerin algı ve tutumları üzerinde yeteri kadar etkide bulunmadığı dikkat çekmektedir. Bu sebeple otel işletmeleri yöneticilerinin genel iç, iç yerleşim ve kayıt yeri değişkenleri konusunda araştırma yapmaları önerilmektedir.

- İstanbul'daki 5 yıldızlı otellerde konaklayan turistlerin çoğunluğunu erkeklerin oluşturmasından dolayı otel sahiplerinin reklamlarında bu detaya dikkat etmeleri, çalışanlarını konuklara nasıl davranacakları konusunda eğitmeleri ve kadın turistleri de turizm olayına katılmalarını daha fazla sağlamak amacıyla çalışmalar ve değerlendirmeler yapılması önerilmektedir.

- Gelecek araştırmalarda otel atmosferinin çalışanların motivasyon ve verimlilikleri üzerine etkileri incelenebilir.

- $\quad$ Otel atmosferi kavramının farklı ölçekler ile ele alınıp tekrar satın alma niyetine ya da müşteri sadakatine olan etkisi araştırılabilir. 
- $\quad$ Araştırmanın tartışma kısmında yer alan genel iç değişkenlerin örneklem üzerinde tekrar satın alma niyetine etkisinin bulunmamasının nedenleri gelecek araştırmalarda ele alınabilir.

Bu araştırma, İstanbul'da 5 yıldızlı otellerde konaklayan turistlerle sınırıdır. Ana kütle sayısının tespit edilemeyecek düzeyde olmasından dolayı ulaşılması gereken örneklemin tam olarak tespit edilememesi çalışmanın kısıtlarından birini oluşturmaktadır. Bu kısıt örneklem sayısını ve örneklem seçim yöntemini etkilemiştir. Araştırmadaki bir diğer kısıt ise zaman ve maliyet kaynaklarının yetersizliğidir. Bu kısıtlar, araştırmanın veri toplama yönetiminin tercihini etkilemektedir. Bu nedenlerle, araştırmadan elde edilecek olan sonuçlar ile ilgili genelleme yapılırken bu kısıtların göz önünde bulundurulması önem arz etmektedir.

\section{Kaynakça}

Akaydın, H. (2007), Perakende Mağaza Atmosferinin Müşterilerin Satın Alma Kararı Üzerindeki Rolü: Eskişehir İlindeki Alışveriş Merkezi Müşterileri ile Bir Araştırma. Yüksek Lisans Tezi, Anadolu Üniversitesi Sosyal Bilimler Enstitüsü İşletme Anabilim Dalı Pazarlama Bilim Dalı, Eskişehir.

Akkuş Karkın, G. (2009), 'Otel İşletmelerinde Hizmet Atmosferi Oluşturulması: Kavramsal Bir Çalışma', Journal of Social Sciences, 6(2), ss. 165-176.

Aksu, M. (2012), Hizmet Kalitesinin Bir Unsuru Olarak Atmosferin Müşteri Sadakati Üzerine Etkisi: Bozcaada'daki Otellerde Konaklayan Yerli Turistler Üzerinde Bir Araştırma. Doktora Tezi, Balıkesir Üniversitesi Sosyal Bilimler Enstitüsü Turizm İşletmeciliği ve Otelcilik Anabilim Dalı, Balıkesir.

Albert, C. B. (1995), 'Predicting Behaviour from Intention-to-Buy Measures: The Parametric Case', Journal of Marketing Research, 32(1), ss. 179-189.

Ali, F., Amin, M., ve Cobanoglu, C. (2016), 'An Integrated Model of Service Experience, Emotions, Satisfaction, and Price Acceptance: An Empirical Analysis in The Chinese Hospitality Industry', Journal of Hospitality Marketing \& Management, 25(4), ss. 449-475.

Altun E. ve Ayyıldız T. (2020), 'Konaklama İşletmelerinde Algılanan Atmosferin Müşteri Tatminine Etkisi: Kuşadası Örneği', Türk Turizm Araştırmaları Dergisi, 4(2), ss. 1294-1311.

Ariffin, F. H., Bibon, F. M. ve Abdullah Raja, S. P. R. (2012), 'Restaurant's Atmospheric Elements: What the Customer Wants', Procedia-Social and Behavioral Sciences, 38, ss. 380-387.

Arslan, M. (2004), Mağazacılıkta Atmosfer. İstanbul: Derin Yayınları.

Asanbakova, G. (2007), Tüketici Davranışları Çerçevesinde Türkiye'yi Ziyaret Eden Rus Turistlerin Tüketim Alışkanlıkları, Yüksek Lisans Tezi, Balıkesir Üniversitesi Sosyal Bilimler Enstitüsü, Balıkesir.

Ayazlar, G. ve Artuğer S. (2015), 'Otel Müşterileri İçin Önemli Olan Atmosferik Unsurların Demografik Özelliklere Göre İncelenmesi', Pamukkale Üniversitesi Sosyal Bilimler Enstitüsü Dergisi, 21(1), ss. 25-33.

Barlı Ö., Aktan, M., Bilgili, B. ve Dare, Ş. (2011), 'Lighting, Indoor Color, Buying Behavior and Time Spent in a Store', Color Research \& Application, 37(6), ss. 465-468.

Bilgili, B., Özkul, E. ve Koç, E. (2018), 'The Influence of Colour of Lighting on Costomers' Waiting Time Perceptions', Total Quality Managemnet \& Business Excellence, 29, ss. 1-14.

Bitner, M. J. (1992), 'Servicescapes: The Impact of Physical Surroundings on Customers and Employees', Journal of Marketing, 56(2), ss. 57-71. 
Booms, B. H. ve Mary J. B. (1982), 'Marketing Services by Managing the Environment', Cornell Hotel and Restaurant Administration Quarterly, 23(1), ss. 35-40.

Countryman, C. ve Jang, S. (2006), 'The Effects of Atmospheric Elements on Customer Impression: The Case of Hotel Lobbies', International Journal of Contemporary Hospitality Management, 18(7), ss. 534-545.

Çabuk, S., Nakıboğlu, M. A. B. ve Canoğlu, M. (2013). 'Algılanan Otel İmajı ve Hizmet Kalitesi ile Tekrar Satın Alma Niyeti Arasındaki İlişkiler', Anatolia: Turizm Araştırmaları Dergisi, 24(1), ss. 96-108.

Güney, D. (2015). Deneyimsel Pazarlamanın Müşteri Sadakatine Etkisi: Muğla'daki Butik Otellere Yönelik Bir Uygulama, Yüksek Lisans Tezi, Muğla Sıtkı Koçman Üniversitesi, Sosyal Bilimler Enstitüsü, Muğla.

Harris, L. C. ve Chris, E. (2008), 'Servicescape and Loyalty Intentions: an Empirical Investigation', European Journal of Marketing, 42(3/4), ss. 390-422.

Heide, M. ve Grønhaug, K. (2006), 'Atmosphere: Conceptual Issues and Implications for Hospitality Management', Scandinavian Journal of Hospitality and Tourism, 6(4), ss. 271-286.

Heide, M. ve Grønhaug, K. (2009), 'Key Factors in Guests' Perception of Hotel Atmosphere', Cornell Hospitality Quarterly, 50(1), ss. 29-43.

Heljic, S. (2015), Milliyet Merkezcilik ve Düşmanlığın Satın Alma Niyeti Üzerindeki Etkisinin Kültürel Benzerlik Çerçevesinde İncelenmesi: Bosna Hersek Örneği, Yüksek Lisans Tezi, Hacettepe Üniversitesi Sosyal Bilimler Enstitüsü, Ankara.

Hellier, P. K., Geursen M. ve Rickard, J. A. (2003), 'Customer Repurchase Intention: A General Structural Equation Model', European Journal of Marketing, 37(11/12), ss. $1762-1800$.

Hoffman, D. K. ve Turiey, W. L. (2014), 'Atmospherics Research: Where do We Go from Here?', Academy of Marketing Science (AMS) Annual Conference, 25(1), Ss. 164-171.

Hui, M. K., Dube, L. ve Chebat, J. C. (1997), 'The Impact of Music on Consumers' Reactions to Waiting for Services', Journal of Retailing, 73(1), ss. 87-104.

Hume D. (2007), An Enquiry Concernıng Human Understanding, (Ed. Peter Millican), New York: Oxford University Press.

Hussain, R. ve Mazhar, A. (2015), 'Effect of Store Atmosphere on Consumer Purchase Intention', International Journal of Marketing Studies, 7(2), ss. 35-43.

Kotler, P. (1963), 'The use of Mathematical Models in Marketing', Journal of Marketing, 27(4), ss. 31-41.

Kurt, G. (2008), Mağaza Atmosferinin Müşteri Sadakati Oluşturmadaki Rolü: Büyük Ölçekli Gıda Perakendeciliğinde Bir Araştırma. Yayınlanmamış Yüksek Lisans Tezi, Dokuz Eylül Üniversitesi Sosyal Bilimler Enstitüsü, İzmir.

Lam, W. L., Chan, W. K., Fong, D. ve Lo, F. (2011), 'Does The Look Matter? The Impact of Casino Servicescape on Gaming Customer Satisfaction, Intention to Revisit, and Desire to Stay', International Journal of Hospitality Management, 30, ss. 558-567.

Lin, I. Y. (2004), 'Evaluating a Servicescape: The Effect of Cognition and Emotion', International Journal of Hospitality Management, 23(1), ss. 163-178.

Lin, I. Y. (2010), 'The Combined Effect of Color and Music on Customer Satisfaction in Hotel Bars', Journal of Hospitality Marketing \& Management, 19(1), ss. 22-37.

Margee, H., Gillian S. M. ve Winzar, H. (2007), 'Exploring Repurchase Intention in A Performing Arts Context: Who Comes? and Why Do They Come Back?', International Journal of Nonprofit and Voluntary Sector Marketing, 12(1), ss. 137-138.

Mei-Fang, C. ve Chia, L. L. (2015), 'The Impacts of Green Claims on Coffee Consumers' Purchase Intention', British Food Journal, 117(1), ss. 195-209. 
Morrin, M. ve Ratneshwar, S. (2000), 'The Impact of Ambient Scent on Evaluation, Attention, and Memory for Familiar and Unfamiliar Brands', Journal of Business Research, 49(2), ss. 157-165.

Oakes, S. (2000), 'The Influence of The Musicscape Within Service Environments', Journal of Services Marketing, 14(7), ss. 539-556.

Özkan Erciyas, F. (2015), Marka Sadakati Oluşturan Müşteri Deneyimlerinin Netnografik Analiz ile İncelenmesi: Kapadokya Bölgesi Beş Yıldızlı Otelleri Örneği, Yüksek Lisans Tezi, Düzce Üniversitesi, Sosyal Bilimler Üniversitesi, Düzce.

Ransley, J. ve Igram, H. (2001), 'What is “Good” Hotel Design?', Facilities, 19(1/2), ss. 79-86.

Schmidt, R. A. ve Sapsford, R. (1995), 'Issues of Gender and Service Scape: Marketing UK Public Houses to Women", International Journal of Retail \& Distribution Management, 23(3), ss. 34-40.

Şahan, Y. (2016), Turizm Pazarlamasında Tüketicilerin Turistik Satın Alma Kararı Üzerinde Etkili Olan Web Sitesi Tasarım Özelliklerinin Nörogörüntüleme Yöntemlerinden Elektroensefalografi (Eeg) ve Göz İzleme Yöntemleriyle Belirlenmesine Dair Deneysel Bir Çalışma, Yüksek Lisans Tezi, Hitit Üniversitesi Sosyal Bilimler Enstitüsü, Çorum.

Taşçı, A. ve Kozak, M. (2006), 'Destination Brands vs Destination Images: Do We Know What We Mean', Journal of Vacation Marketing, 12(1), ss. 299-315.

Tek, Ö. B. ve Demirci, F. (2006), Perakende Pazarlama Yönetimi, İzmir: Birleşik Matbaacılık.

Temeloğlu, E., Taşpınar, O. ve Soylu, Y. (2017), 'Yiyecek ve İçecek İşletmelerinde Atmosfer, Tüketim Duyguları, Müşteri Memnuiyeti ve Yeniden Satın Alma Davranışı Arasındaki İlişkinin İncelenmesi', Journal of Tourism and Gastronomy Studies, 5(2), ss. 253-264.

Turgut, M. Ü. (2014), Marka Sevgisinin Marka Güveni, Olumsuz Bilgiye Karşı Direnç ve Tekrar Satın Alma Niyeti Çerçevesinde İncelenmesi. Yüksek Lisans Tezi, Hacettepe Üniversitesi, Sosyal Bilimler Enstitüsü, Ankara.

Turley, L. W. ve Milliman, E. R. (2000), 'Atmospheric Effects on Shopping Behavior: A Review of the Experimental Evidence', Journal of Business Research, 49(2), ss. 193-211.

Ural, A. ve Kılıç, İ. (2005), Bilimsel Araştırma Süreci ve SPSS ile Veri Analizi. Ankara: Detay Yayıncılık.

Uşaklı, A. (2016), Turistik Tüketici Deneyimi: Beş Yıldızlı Resort Otellerde Bir Uygulama, Doktora Tezi, Gazi Üniversitesi Eğitim Bilimleri Enstitüsü, Ankara.

Varlander, S. ve Yakhlef, A. (2006), 'The Interplay of Service Complexity and Spatial Layouts', International Journal of Retail \& Distribution Management, 34(10), ss. 722-741.

Vikas, M. ve Wagner, A. K. (2011), 'Satisfaction, Repurchase Intent, and Repurchase Behaviour: Investigating The Moderating Effect of Customer Characteristics', Journal of Marketing Research, 38(1), ss. 131-142

Yang, Y. S. (2008), The Resort Hotel Experience: Conceptualization, Measurement and Relation to The Antecedents and Consequences. Doctoral Dissertation, The Hong Kong Polytechnic University, Hong Kong.

Yeniçeri Alemdar, Mine (2010). Deneyimsel Pazarlamada Alışveriş Atmosferinin Tüketici Davranışları Üzerindeki Etkisi. Doktora Tezi, Ege Üniversitesi Sosyal Bilimler Enstitüsü Halkla İlişkiler ve Tanıtım Anabilim Dalı, İzmir.

Yolcu, E. (2006), Şehir Otelleri, Çevre, Mekân, Tasarım İlkeleri Üzerine. Yüksek Lisans Tezi, Marmara Üniversitesi Güzel Sanatlar Enstitüsü, İstanbul.

Young, P. V. (1968), Bilimsel Sosyal İncelemeler ve Araştırma (Çev. G. Bingöl ve N. İş̧il). Ankara: Ege Matbaası. 